\title{
Sport Tourism Event of Tour De Singkarak to Support Destination Management in West Sumatera, Indonesia
}

\author{
Bet El Silisna ${ }^{1}$ and Retnaningtyas Susanti ${ }^{2}$ \\ ${ }^{1}$ Tourism Dept. Manado State Polytechnic, Indonesia \\ ${ }^{2}$ Faculty of Tourism and Hospitality, Padang State University, Indonesia
}

Corresponding Author: betel.lagarense@gmail.com

\section{ARTICLE INFO}

Received

3 December 2019

Accepted

15 February 2020

Available online

31 March 2020

\section{ABSTRACT}

This study aims to analyze the sport tourism event of Tour de Singkarak (TdS) related to tourist destination management in West Sumatera, Indonesia. The TdS is an international road bicycle race held annually for ten-year period as data presented from 2009 to 2018. Data were collected for this study through in-depth interviews with informants and analyzed by a descriptive qualitative technique. The results showed that the TdS events were succesfully and consistently held annually for ten-year period of 2009-2018 in West Sumatera and has significantly contributed to the regionas tourism destination. This was due to a strong commitment and serious action among central government and local government at province and municipality levels for the sport tourism development at the tourism destination in West Sumatera. The commitment could be seen in the serious, strong commitment and coordination between the Ministry of Tourism and the National Road Development Agency at a central government and Heads of Local Departments of Tourism, of Public Works and of Transportation at province and regency/municipality level. The commitment could be seen from the sport tourism management such as the provision of shared budget, event coordination, and destination and infrastructure development and promotion. This has especially raised an integrated development and improvement of infrastructures, i.e. roads, transportation mode, and accomodation facilities with increasing quantity and quality. It is a fact that $\mathrm{TdS}$ could be held annually for ten-year period (2009-2018) along with proper and good destination management for sport tourism in West Sumatera Province

Keywords: Tour de Singkarak, event, sport tourism, destination management. 


\section{INTRODUCTION}

\section{Sport Tourism}

Sports tourism is defined as shortterm activities related to tourism, economic impacts, spending on facilities and infrastructure preparation, as well as income from visitors and exposure to mass media (Getz, 2007: 15). Getz's definition above shows that event including sport tourism event influences infrastructure, tourism, and the economy of the host region. Susanti et al (2017) explains that sport events can be categorized according to its scales: big, medium, and small in which big event is a match participated by countries all over the world. Medium event is participated by countries in a certain region, while small event is participated by regions in a country. Indonesia has some international scale sport events and was a host for some regional and international events. Event implementation in a short time remains influential on the host in the long run. The event organiser need to develop a new method for regional development, especially in terms of infrastructure and image. The impact of event on infrastructure brings a positive image for the host. The development of infrastructure is in line with the development of the image (Smith, 2005). Infrastructure development that can be http://ojs.unud.ac.id/index.php/eot utilized by sport tourists and visitors give a positive image for the host. A good image of infrastructure can be one of the tourist attractions (Brown, Chalip, Jago, \& Mules, 2004; Kim \& Chalip, 2004). Ritchie and Smith (1991) state that organizing sports tourism increases awareness of destinations.

Baade and Matheson (2003) in their research on the 1984 Los Angeles Olympics found that the event succeeded in opening and increasing employment, as well as improving the quality of infrastructure. Large inventions induce the creation of industries that absorb labor, one of which is the accommodation industry. Sport tourism of World Cup Japan and South Korea in 2002 has increased the number of tourists from various countries reached 46,000 inhabitants. The large number of tourists requires accommodation as their temporary shelter, therefore the accommodation infrastructure needs to be developed, so that the needs of tourists are met. The contribution of sports tourism has increased in the quantity and quality of large infrastructure. Quality road is one form of contribution from sports tourism. The quality of the road has an effect on increasing people's travel for trips, both using public and private modes of transportation. People attending the sport tourism events tend to choose to use 
private modes of transportation if the road to be passed to get to the tourist destination has good quality. Another thing that affects travel is the number and quality of modes of public transportation. If there are few modes of public transportation and conditions are not good, then tourists will prefer to travel using private vehicles. Previous research (Susanti et al, 2017) stated that Tour de Singkarak (TdS) is one of sport tourisms held by West Sumatera Government since 2009 and cycling race was chosen as an effort to improve tourist attraction in West Sumatera because of the history of this sport itself. Thus, sustainability of sports tourism is interesting to study, especially for analyzing the destination management strategy with roles of stakeholder collaboration and adequate infrastructures for the development of sustainable tourism in the international road bicycle race of TdS for ten-year period (2009-2018) in West Sumatera, Indonesia.

\section{Desination Management}

Destination Management and Marketing Organization (DMMOs) have recently became a mainstream factor in identifying successful development of a destination and its perspectives for better position in highly competitive tourism markets. They are not only representing a specific destination but are also striving to http://ojs.unud.ac.id/index.php/eot community development that bring longterm benefits such as attracting more visitors, increasing the economic gains, facilitating future marketing and product development decisions, and generally contributing to regional development through improving community relations and partnership (Timareva et al, 2015). Willingness to host sport tourism events at the destination requires large capital, especially for infrastructure, operational costs, and management of activities. The implementation of sports events is one of the efforts to create investment in infrastructure in general that will lead to economic growth.

Sports infrastructure includes the stadium or venue for the race as the main part and the road, transportation and accommodation as a supporting part. Infrastructure is needed to mutually support the implementation of activities, such as roads and stadiums (Matheson, 2008). Accroding to Sitepu (2019, the important indicator of the good governance of tourism in the priority destination where the destination has run the management and development of tourism and destination with the principles of Sustainable Tourism Development (STD). According to Simanihuruk (2019). It can be concluded that tourism facilities are the convenience of visitors to enjoy, feel the comfort that has been provided by 
a tourist attraction that has facilities in order to satisfy or achieve the satisfaction of visitors to a tourist destination.

\section{Tourism Sustainability}

The idea of sustainability in tourism arises from the recognition that tourism activities can lead to a decline in natural resources, both at short and long terms. It is the main reason that the principles of sustainable development should be the focus for tourism as a mechanism for development (Fathimath, 2015). For this reason, sustainability must be applied to all areas that include key attractions, supporting factors, and infrastructures that contribute to tourism destination competitiveness in tourism development and all forms of tourism, including mass tourism (UNWTO, 2015).

Sustainability must be applied so that any tourism events can be held continuously over years without negative impacts on the environment. In this context, support from stakeholders such as government, business sector, and local community, is very strategic for the development of sustainable tourism (Byrd, 2007). Kencana (2019) explains that the immediate effects of tourism at this destination especially for the improvement of economic benefits have come from visitors' activities. However, to make it sustainable, the local people must also http://ojs.unud.ac.id/index.php/eot empower their capacity as well as their competencies in providing qualified tourism products/services. The events industry, including festivals, meetings, conferences, exhibitions, incentives, sports and a range of other events, is rapidly developing and makes a significant contribution to business and leisure related tourism. Events are important motivator of tourism, and figure prominently in the development and marketing plans of most destinations (Getz, 2008: 403 - 428). Acording to Ardani (2017) for special event with job fair activities, easy access by public transport and large parking area are considered very important by the visitors. It does make sense because the job seekers in general use public transport or motorcycle as their transportation. The most important indicators of site selection for such event are the easy access, the availability of the public transportation, as well as the availability of rooms with different activities such as seminar and presentation.

\section{The Needs of Infrastructure}

Infrastructure is more focused on providing preconditions for development, in this case tourism development (Mandic, Mrnjavac, and Kordic, 2018). The infrastructure development facilitates access for communities and visitors. In a tourism development, infrastructures are 
deliberately built to provide tourists with access to carry out tourism activities. This tourism infrastructure is related to all elements in a destination that enable and encourage the tourism development (Swarbrooke and Horner, 2001). In a broader sense, such infrastructure includes all facilities used by the tourists when they leave homes, reach tourism destination, and return home (Lohmann and Netto, 2017). In fact, most tourism infrastructures are continuously used by local residents and only used by the tourists in certain periods (Hadzik and Grabara 2014). Tourism infrastructure development is related to the development of sustainable tourism (Sharpley, 2009). Once built, tourism infrastructure can affect the competitiveness of tourism destination, increases the efficiency of production and distribution of tourism services, and allows the supply of tourism services (Mandic, Mrnjavac, and Kordic, 2018).

In a bicycle race as a form of sports tourism, the infrastructures required to support tourism development are roads, transportation modes, and accommodation facilities for the tourists. Deenihan and Caulfield (2015) have examined how tourists assess different types of tourism infrastructure and they are ready to double cycling time if good infrastructures are available. Gunawijaya and Pratiwi (2016) stated that repairing, structuring and http://ojs.unud.ac.id/index.php/eot developing the tourism destinations based on local culture and environmental sustainability is the best strategy to develop tourism development.

This strategy consists of tourist attractions development, variety activities, improvement of infrastructure, accessibility, and organizes the events. Therefore, the organizing committee of a road bicycle race event should work together among stakeholders to build new infrastructures and improve the existing ones to support tourism development in accordance with what is needed by racers as tourists, so that the road bicycle race as a form of sports tourism events can be sustainable. The stakeholders can include government, private sector, and local community, particularly in the development of tourism infrastructure.

\section{METHOD}

Based on the assumption and aims of the study, the researchers conducted this research using a descriptive qualitative method to explore information in-depth with a semi-structured interview technique from a number of informants to understand the stakeholder collaboration model applied at the TdS event. The informants interviewed were the organizing committees (authorities in Local Government Units such as the Sub- 
Departments of Tourism, of Public Works, and of Transportation at province and regency/municipality level as well as the Police and Event Organizer/EO), especially for examining the collaborative approach they adopted as stakeholders in the 2018 TdS event. In-depth interviews were also conducted with racer teams and officials as well as invited guests to understand their perceptions on the availability of infrastructure and its quantity and quality, viewed from roads, transportation modes, and accommodation facilities. Such interviews were also conducted with a number of spectators and local people, especially at the start and finish locations in each stage of the TdS event in certain tourism attractions to understand their perceptions on the successful TdS events they witnessed. The research data were analyzed by a descriptive qualitative technique by classifying the results of in-depth interviews according to the aims of the study and used to analyze the stakeholder collaboration approach for the development of sustainable tourism in the TdS events held annually in West Sumatera for ten-year period (2009-2018).

\section{RESULTS AND DISCUSSION}

\section{Tour de Singkarak}

Most of the TdS participants came from international teams that had agreed to international bicycle racing events. The number of countries that are part of the TdS has increased from 2009 to 2017, but it is different from the number of teams and the number of participants which has fluctuated. The highest number of participating countries occurred in 2015 and the lowest in 2011. The TdS implementation report showed the average number of teams needed was 23 teams, the lowest of 20 teams, the highest of 25 teams. The average number of participants was 180 people, the highest in 2012 (250 people) and the lowest in 2018 (106 people). The number of $\mathrm{TdS}$ participants from 2009 - 2017 depends on fluctuations, factors that affect athlete performance and implementation schedules. National and local participants reduce the amount due to achievement factors that do not meet the standards for entering TdS qualifications. The teams that successfully escaped and became part of the TdS from 2009 - 2015 were the National Team, the Pegasus Cycling Team, KFC Jakarta and the Banyuwangi Highway Cycling Club. 
Pegasus Cycling Team Indonesia is the official representative of Indonesia for some international scale cycling events such as Tour de China and Tour de Langkawi (Informant 1). In 2009 there were 10 domestic teams from $25 \mathrm{TdS}$ participating teams, in 2015 there were only 5 domestic teams left from the 24 participating teams (TdS Report). One of the conditions that must be met by $\mathrm{TdS}$ to get a class increase is to increase the number of world riders and reduce the number of national teams (UCI). Tour de Singkarak (TdS) is an official international road bicycle race event combining sports and tourism activities by cycling at a long distance of several stages in West Sumatera Province. The event was held for ten-year period (2009-2018). The name Singkarak is taken from name of the largest lake in West Sumatera. Lake Singkarak is located in three regencies, i.e.: Tanah Datar, Solok, and South Solok. This sport activity is carried out by cycling across 18 regencies/municipalities in West Sumatera, except Mentawai Regency. TdS is a sports tourism event held annually for the development of sustainable tourism in West Sumatera. TdS is categorized as a class 2.2 event of Asia Tour, similar to the event like the Tour de Langkawi (TdL) in Malaysia where racers from various countries can participate and also included in the official calendar of world cycle http://ojs.unud.ac.id/index.php/eot organization

(Union

Cycliste

Internationale-UCI) ） (www.uci.org). The initial moment of TdS began from a tourism attraction of Taplau Beach in Padang City and finished at Lake Singkarak, Solok Regency. Along the road bicycle race, there are various interesting tourism attractions. The event was designed to pass through various leading tourism attractions in West Sumatera. The selection of routes shows that it is a sports tourism event organized through a stakeholder collaboration at provincial and regency/municipality level for the development of sustainable tourism over years in West Sumatera.

\section{Destination Management for Tour de Singkarak}

The implementation of sports events only lasts for a short period of time, but the impact of infrastructure development can be felt by the community over a long period of time. Destination management including infrastructure has been prepared for an event competition that used as a public space. Tourist attraction during the TdS as sport tourism event has increased economic and social value for the region and the community. 
Table 1. Tourism attraction in West Sumatera

\begin{tabular}{|c|c|c|c|}
\hline No & Potentials & $\begin{array}{l}\text { Tourist } \\
\text { Atraction }\end{array}$ & Location \\
\hline \multirow[t]{5}{*}{1} & Mountain & Mt. Merapi & $\begin{array}{l}\text { Padang Panjang } \\
\text { City }\end{array}$ \\
\hline & & Mt. Singgalang & Agam Regency \\
\hline & & Mt. Talang & $\begin{array}{ll}\text { South } & \text { Solok } \\
\text { Regency } & \end{array}$ \\
\hline & & Mt. Tandikek & $\begin{array}{l}\text { Padang Pariaman } \\
\text { Regency }\end{array}$ \\
\hline & & Mt. Talamau & $\begin{array}{l}\text { West Pasaman } \\
\text { Regency }\end{array}$ \\
\hline \multirow[t]{4}{*}{2} & Hills & Peak Lawang & Agam Regency \\
\hline & & PeakLangkisau & $\begin{array}{ll}\text { South } & \text { Coastal } \\
\text { Regency } & \end{array}$ \\
\hline & & $\begin{array}{l}\text { Peak Barisan } \\
\text { (Kelok 9) }\end{array}$ & Payakumbuh City \\
\hline & & Peak Gagoan & Solok Regency \\
\hline \multirow[t]{5}{*}{3} & Lake & Lake Singkarak & $\begin{array}{l}\text { Solok City \& } \\
\text { Tanah } \\
\text { Regency }\end{array}$ \\
\hline & & Lake Maninjau & Agam Regency \\
\hline & & $\begin{array}{l}\text { Lake Atas dan } \\
\text { Bawah }\end{array}$ & $\begin{array}{ll}\text { South } & \text { Solok } \\
\text { Regency } & \end{array}$ \\
\hline & & Lake Talang & Solok Regency \\
\hline & & Lake Tomosu & Sawahlunto City \\
\hline \multirow[t]{3}{*}{4} & Valley & Valley Harau & Payakumbuh City \\
\hline & & Valley Anai & $\begin{array}{ll}\text { Tanah } & \text { Datar } \\
\text { Regency } & \end{array}$ \\
\hline & & Valley Sianok & Bukittinggi City \\
\hline \multirow[t]{3}{*}{5} & $\begin{array}{l}\text { Water } \\
\text { Falls }\end{array}$ & 100 tingkek & Padang City \\
\hline & & Nyarai & $\begin{array}{l}\text { Padang Pariaman } \\
\text { Regency }\end{array}$ \\
\hline & & Sarasah Donat & 50 Koto Regency \\
\hline \multirow[t]{5}{*}{6} & River & Jembatan Akar & $\begin{array}{ll}\text { South } & \text { Coastal } \\
\text { Regency } & \\
\end{array}$ \\
\hline & & Lubuk Minturun & Padang City \\
\hline & & Batang & $\begin{array}{l}\text { Dharmasraya } \\
\text { Regency }\end{array}$ \\
\hline & & Rimbo Panti & Pasaman Regency \\
\hline & & Kuantan & $\begin{array}{l}\text { Sijunjung } \\
\text { Regency }\end{array}$ \\
\hline \multirow[t]{6}{*}{7} & Beach & Air manis & Padang City \\
\hline & & Tiram & $\begin{array}{l}\text { Padang Pariaman } \\
\text { Regency }\end{array}$ \\
\hline & & Gondoriah & Pariaman City \\
\hline & & Mandeh Island & $\begin{array}{ll}\text { Pesisir Selatan } \\
\text { Regency }\end{array}$ \\
\hline & & Siberut Island & $\begin{array}{l}\text { Mentawai } \\
\text { Archipelago } \\
\text { Regency }\end{array}$ \\
\hline & & Sasak & $\begin{array}{l}\text { West Pasaman } \\
\text { Regency }\end{array}$ \\
\hline
\end{tabular}

Source: Survey, 2018
Table 1 representing various tourism attraction in West Sumaterwe. The implementation of the TDS acts as a trigger for tourist attraction management and regional development, ranging from amenities to accessibility for tourism. Tourism can be used as an alternative to regional income so that its potential needs to be optimized. The potential of tourism in West Sumatera through which TDS is very diverse, ranging from natural attractions to artificial and cultural.

\section{Promotion of TdS as Sports Tourism Event}

Promotion in the form of advertising on TV is supported by the background of natural beauty and culture that stretches in the Province of West Sumatra. One of the strengths of implementing $\mathrm{TdS}$ is the collaboration between the tourism ministry and several national and international TV stations to promote what, where, when, why, and how TdS takes place. During the nine times of TdS implementation, only about the last 3 years the TdS advertisement aired on the national Metro TV station. Advertising in national media is one of the tasks of the Ministry of Tourism. Advertising in local media is the responsibility of the provincial and district and city governments. 
Table 2. A Summary of the TdS Events for Ten-year period (2009-2018)

\begin{tabular}{lllllllllll}
\hline TdS & $\mathbf{2 0 0 9}$ & $\mathbf{2 0 1 0}$ & $\mathbf{2 0 1 1}$ & $\mathbf{2 0 1 2}$ & $\mathbf{2 0 1 3}$ & $\mathbf{2 0 1 4}$ & $\mathbf{2 0 1 5}$ & $\mathbf{2 0 1 6}$ & $\mathbf{2 0 1 7}$ & $\mathbf{2 0 1 8}$ \\
\hline Regency/ Municipality & 4 & 6 & 12 & 14 & 17 & 18 & 18 & 17 & 18 & 16 \\
\hline Stages/Days & 4 & 6 & 7 & 7 & 7 & 9 & 8 & 8 & 9 & 8 \\
\hline Countries & 11 & 15 & 15 & 18 & 24 & 23 & 26 & 18 & 25 & 26 \\
\hline Teams & 25 & 22 & 25 & 25 & 21 & 20 & 24 & 23 & 25 & 20 \\
\hline INA Teams & 10 & 11 & 11 & 9 & 6 & 6 & 5 & 5 & 5 & 5 \\
\hline Foreign Teams & 15 & 11 & 14 & 16 & 15 & 14 & 19 & 18 & 15 & 15 \\
\hline Racers & 225 & 217 & 225 & 250 & 220 & 131 & 135 & 109 & 108 & 114 \\
\hline Track (km) & 188 & 551.7 & 743.5 & 854 & 117.3 & 1,250 & 1,342 & 1,074 & 1,226 & 1,267 \\
\hline Prizes (Million) & 600 & 750 & 750 & 1,000 & 1,200 & 1,300 & 1,400 & 2,200 & 2,300 & 2,300 \\
\hline Time & Apr-May Jun & Jun & Jun & Jun & Jun & Oct & Aug & Nov & Nov \\
\hline
\end{tabular}

Source: Data processed, 2019

The division was realized because of good coordination between various parties, not limited to agencies with an interest in the field of tourism, but other midwives such as: Public Works Agency (Road Infrastructure and Spatial Settlement), Transportation Department, Health Office, and no less important is the National Police and the TNI. This means that $\mathrm{TdS}$ is a real blend of sport and tourism, as an effort to promote tourism which provides an opportunity for racers to act as tourists, enjoying the beauty of the natural charm that unfolds. The racers become "advertising stars" tourist attraction, when they are covered by the mass media with a background of natural or cultural barriers, viewers from various other regions can also watch and begin to generate interest to visit the location. The main objective of the implementation of the TDS program is to promote the potential of regional tourism through print media and electronic media.
The selection of routes around the tourist area is a strategy of combining tourism and bicycle racing. Every year the number of tourist attractions that are part of the start or finish location increases. The start and finish position attracting more spectators to gather than the area that is just passed. The TdS as sport tourism events were held annually in West Sumatera Province at different times. The timing changed over years in accordance with the Asia Tour race schedule issued by UCI.

Table 2 shows a summary of TDS events for ten-year period (2009-2018). The events were usually held between April and June for one week. However, in 2015 the event was held in October, in 2016 August, in 2017 November, and in 2018 November as the events must be adjusted to the world road bicycle racing season and the readiness of shared budget among regencies/municipalities involved. 
However, the events were successfully held annually for ten-year period (20192018).

\section{Contribution and Coordination}

The implementation of $\mathrm{TdS}$ in West Sumatra Province has made a positive contribution in the field of infrastructure. Contributions that can be seen are the roads becoming smoother, lodging is easily found in the area, and public transportation is increasingly easy. TdS as a sport tourism has successfully become the main event in the province of West Sumatra which consists of 19 Regencies and Cities. The advantage of TdS is good coordination between various regencies, cities and ministries. Coordination is one of the obstacles faced by several regions that try to organize events, especially with other goverement and private agencies not only the tourism office but also public works office, and transportation agency. The involvement of the regency and the city as the host has increased because of the awareness that TdS has given indirect investment for the region. Potential, especially the main attractions of the region are promoted through TdS, and supported by good road infrastructure to make it more attractive for tourists coming after TdS. On one hand, TdS increases regional expenditure, but on the other hand, TdS helps promote http://ojs.unud.ac.id/index.php/eot the region. The TdS event coordination meetings were held regularly from the end of TdS activities in the previous period to before the implementation of TdS in the next period.

These meetings were adjusted to the TdS schedule, and for ten-year period they were held between April and November and most was held in the middle, i.e. June. Such event coordination was a strategic factor influencing the sustainability of TDS events held annually for ten-year period (2009-2018). Each stakeholder had an authority to maintain the roads, namely: national roads under the authority of the National Road Development Agency as well as provincial and regency/ municipal roads under the authority of the Sub-Department of Public Work maintaining the roads accross all regencies/municipalities in West Sumatera.The stakeholders from central, provincial, and regency/municipality governments have proven to be able to coordinate well to maintain the roads along the $\mathrm{TdS}$ routes so that the $\mathrm{TdS}$ event can be held annually for ten-year period (2009-2018). 


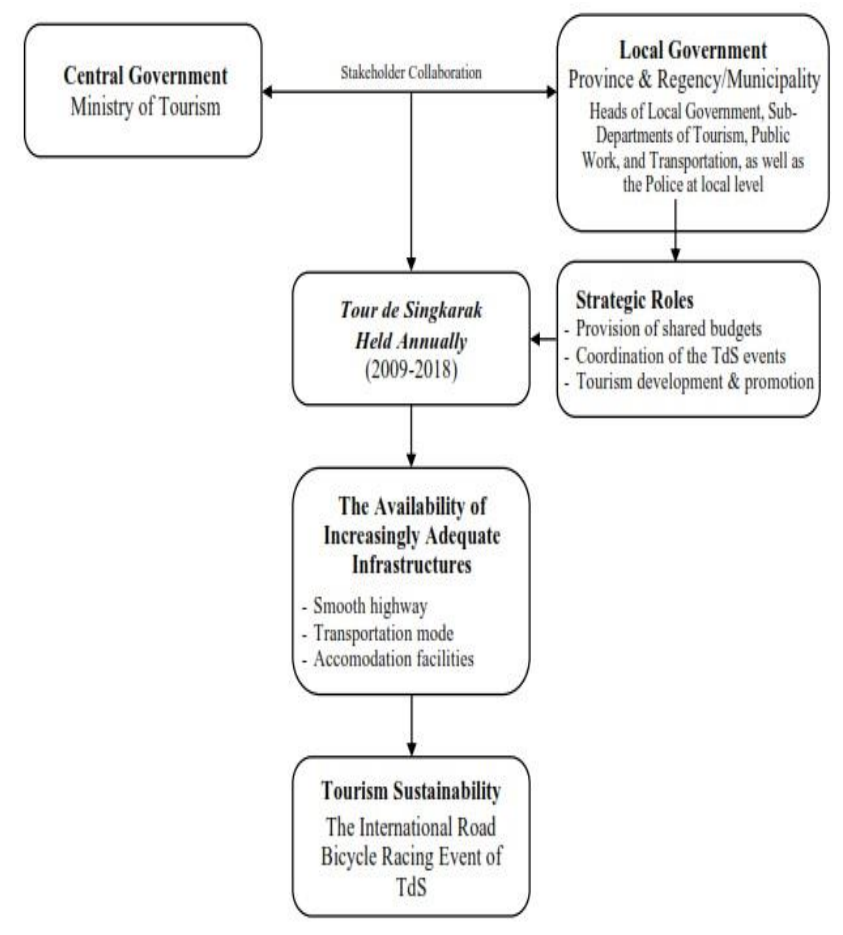

Figure 1. Collaboration and coordination among stakeholders at central and local government levels

(Source: Primary data processed, 2019)

Stakeholder collaboration through event coordination among the organizing committees in West Sumatera can also be seen in the process of determining the routes for the $\mathrm{TdS}$ events for ten-year period (2009-2018). The determination of these routes involved three parties, i.e. regency/municipal, provincial and central governments. They were actively involved in the coordination until the stage of finalization of $\mathrm{TdS}$ events accross regencies/municipalities in West Sumatera. Figure 1 shows the flow in the determination of $\mathrm{TdS}$ routes involving the stakeholders from provincial and regency/municipal and central governments. At the local level authorities involved in coordinating the determination of TdS routes were Heads of Local Governments as well as the SubDepartments of Tourism, of Public Works and of Transportation. The SubDepartment of Tourism coordinated the TdS events because TdS is basically a sports tourism event. The Sub-Department of Public Works maintained roads along the TdS routes in West Sumatera.

The Sub-Department of Transportation provided the traffic signs and conducted a traffic congestion engineering. Meanwhile, the police in West Sumatera secured the events so that the racers could safely race. At the central level, the parties involved were the Ministry of Tourism and the Race Controller. The finalization in the determination of $\mathrm{TdS}$ routes was done through coordination involving the Ministry of Tourism and the SubDepartments of Tourism, of Public Works, and of Transportation, as well as the Event Organizer.

\section{Tourism Development}

For developing the sustainable tourism in West Sumatera, stakeholders designed TdS to pass through most of the leading tourism attractions at each regency/municipality. $\mathrm{TdS}$ is a concrete integration of sports and tourism as well as one of the efforts to develop and promote e-ISSN: 2407-392X. p-ISSN: 2541-0857 
the sustainable tourism that provide racers and their official teams with opportunity to be tourists enjoying the beauty of natural scene exposured. The racers are the "advertising stars" of tourism attractions when they were covered by mass media with the background of natural beauty or culture and viewers from various other regions can also watch and begin to generate interest to visit the location.

Table 3. Promotion of Tourism attractions in the TdS Events in West Sumatera

\begin{tabular}{|c|c|c|c|}
\hline No. & Locations & $\begin{array}{l}\text { Period } \\
\text { of } \\
\text { TdS } \\
\end{array}$ & $\begin{array}{l}\text { Tourism } \\
\text { Attractions }\end{array}$ \\
\hline 1. & $\begin{array}{l}\text { Padang } \\
\text { Panjang } \\
\text { Municipality }\end{array}$ & $\begin{array}{l}2009- \\
2018\end{array}$ & Mount Marapi \\
\hline 2. & $\begin{array}{l}\text { Agam } \\
\text { Regency }\end{array}$ & $\begin{array}{l}2010 \\
2014- \\
2018\end{array}$ & $\begin{array}{l}\text { Mount Singgalang, } \\
\text { Puncak Lawang } \\
\text { Hill, Lake } \\
\text { Maninjau, Lawang } \\
\text { Park }\end{array}$ \\
\hline 3. & $\begin{array}{l}\text { South Solok } \\
\text { Regency }\end{array}$ & $\begin{array}{l}2009 \\
2011 \\
2016- \\
2018\end{array}$ & $\begin{array}{l}\text { Mount Talang, } \\
\text { Twin Lake (Up and } \\
\text { Bottom) }\end{array}$ \\
\hline 4. & $\begin{array}{l}\text { Padang } \\
\text { Pariaman } \\
\text { Regency }\end{array}$ & $\begin{array}{l}2012 \\
2018\end{array}$ & $\begin{array}{l}\text { Golf Field, Anai } \\
\text { Valley, Mount } \\
\text { Tandikek, Nyarai } \\
\text { Waterfall, Tiram } \\
\text { Beach }\end{array}$ \\
\hline 5. & $\begin{array}{l}\text { Pariaman } \\
\text { Municipality }\end{array}$ & $\begin{array}{l}2010- \\
2018 \\
\end{array}$ & Gondoriah Beach \\
\hline 6. & $\begin{array}{l}\text { Pasaman } \\
\text { Regency }\end{array}$ & $\begin{array}{l}2013- \\
2018\end{array}$ & $\begin{array}{l}\text { Equator } \\
\text { Monument, Rimbo } \\
\text { Panti River }\end{array}$ \\
\hline 7. & $\begin{array}{l}\text { West } \\
\text { Pasaman } \\
\text { Regency } \\
\end{array}$ & $\begin{array}{l}2013- \\
2018\end{array}$ & $\begin{array}{l}\text { Mount Talamau, } \\
\text { Sasak Beach }\end{array}$ \\
\hline 8. & $\begin{array}{l}\text { South Pesisir } \\
\text { Regency }\end{array}$ & $\begin{array}{l}2012- \\
2018\end{array}$ & $\begin{array}{l}\text { Puncak Langkisau } \\
\text { Hill, Jembatan } \\
\text { Akar River, } \\
\text { Mandeh Island } \\
\text { Beach, Carocok } \\
\text { Beach } \\
\end{array}$ \\
\hline 9. & $\begin{array}{l}\text { Payakumbuh } \\
\text { Municipality }\end{array}$ & $\begin{array}{l}2011- \\
2018\end{array}$ & $\begin{array}{l}\text { Ngalau Indah Café, } \\
\text { Kelok } 9 \text { Bridg, } \\
\text { Harau Valley }\end{array}$ \\
\hline
\end{tabular}

http://ojs.unud.ac.id/index.php/eot

\begin{tabular}{|c|c|c|c|}
\hline 10. & $\begin{array}{l}\text { Solok } \\
\text { Regency } \\
\end{array}$ & $\begin{array}{l}2009- \\
2018 \\
\end{array}$ & $\begin{array}{l}\text { Puncak Gagoan } \\
\text { Hill, Lake Talang }\end{array}$ \\
\hline 11. & $\begin{array}{l}\text { Solok } \\
\text { Municipality }\end{array}$ & $\begin{array}{l}2014- \\
2018\end{array}$ & $\begin{array}{l}\text { City Park, Lake } \\
\text { Singkarak }\end{array}$ \\
\hline 12. & $\begin{array}{l}\text { Tanah Datar } \\
\text { Regency }\end{array}$ & $\begin{array}{l}2009- \\
2018\end{array}$ & $\begin{array}{l}\text { Baso Pagaruyung } \\
\text { Palace, Lake } \\
\text { Singkarak, Anai } \\
\text { Valley }\end{array}$ \\
\hline 13. & $\begin{array}{l}\text { Sawahlunto } \\
\text { Municipality }\end{array}$ & $\begin{array}{l}2009- \\
2018\end{array}$ & $\begin{array}{l}\text { Tourism Park of } \\
\text { Kandi, Lake } \\
\text { Tomosu }\end{array}$ \\
\hline 14. & $\begin{array}{l}\text { Bukittinggi } \\
\text { Municipality }\end{array}$ & $\begin{array}{l}2009- \\
2018\end{array}$ & $\begin{array}{l}\text { Jam Gadang (Big } \\
\text { Clock), Sianok } \\
\text { Valley }\end{array}$ \\
\hline 15. & $\begin{array}{l}\text { Padang } \\
\text { Municipality }\end{array}$ & $\begin{array}{l}2014- \\
2018\end{array}$ & $\begin{array}{l}\text { Cultural Park, } 100 \\
\text { Tingkek Waterfall, } \\
\text { Lubuk Minturun } \\
\text { River, Air Manis } \\
\text { Beach, Taplau } \\
\text { Padang } \\
\end{array}$ \\
\hline 16. & $\begin{array}{l}50 \text { Koto } \\
\text { Regency }\end{array}$ & $\begin{array}{l}2011- \\
2012 \\
2016- \\
2018\end{array}$ & $\begin{array}{l}\text { Harau Valley, } \\
\text { Waterfall Sarasah } \\
\text { Donat }\end{array}$ \\
\hline 17. & $\begin{array}{l}\text { Dharmasraya } \\
\text { Regency }\end{array}$ & $\begin{array}{l}2015- \\
2018 \\
\end{array}$ & $\begin{array}{l}\text { Sport Center, } \\
\text { Batang River }\end{array}$ \\
\hline 18. & $\begin{array}{l}\text { Sijunjung } \\
\text { Regency }\end{array}$ & $\begin{array}{l}2014- \\
2018\end{array}$ & $\begin{array}{l}\text { Silokek Pasir } \\
\text { Putih, Pancasila } \\
\text { Building, Tourism } \\
\text { Village, Kuantan } \\
\text { River }\end{array}$ \\
\hline
\end{tabular}

Source: Survey data processed, 2018

Table 3 shows that stakeholders in West Sumatera have since the beginning designed that the TdS held annually passed through all those leading tourism attractions for the development of sustainable tourism in the region. Since held for the first time in 2009, the TdS events have consistently offered a mix of sports and tourism, especially road bicycle race and tourism attractions spreading throughout the regencies/municipalities in West Sumatera. In 2018, teams from various countries with professional racers who have competed in various international events participated. TdS has e-ISSN: 2407-392X. p-ISSN: 2541-0857 
been an attractive sports tourism activity for racers and their officials who deliberately come and compete. Their purpose was not only to train their abilities, compete and win prizes, but also enjoy the natural and cultural beauty in West Sumatera.

The start and finish locations with unique tourism attractions become one of the goals of racers and their officials to come back in the future. The goal of TdS events is to promote the potentials of tourism attractions by persuading the arrival of people to watch the road bicycle race in various regions. The promotion through advertising on television was supported by beautiful natural and cultural scenery across West Sumatera regions. An interesting phenomenon in the TdS events held annually is stakeholder collaboration between the Ministry of Tourism and both national and international television stations to promote what, where, when, why, and how the TdS events are held. Advertising in national media is a part of the Ministry of Tourism's tasks, while advertising in local media is the responsibility of provincial and regency/municipality governments. For the communities in West Sumatera, the promotion of TdS events aimed to remind them about a big party (alek gadang) that will soon be held around their area.

http://ojs.unud.ac.id/index.php/eot
The Availability of Tourism

Infrastructure

The willingness of regency/municipal governments to be the host for the $\mathrm{TdS}$ events required a large amount of capital for roads, operational costs, and event management. This means that the availability of investment to build and maintain the adequate infrastructures for TDS was the most important factor to determine whether or not the TDS events could be held in each regency/municipality annually. If a regency/municipal government was unable to provide the investment or budget for the construction and improvement of infrastructure, the TdS events would not be held in the regency/municipality itself. Sport infrastructures required in the TdS events were smooth roads, diverse transportation modes, and accommodation facilities with star ratings.

Investment in the development and maintenance of the infrastructures over years was strategic not only for the TdS events held annually, but also to make the infrastructures the public goods for the development of sustainable tourism with high socio-economic values for local communities in the long run. From the beginning, central government through the Ministry of Tourism and local governments (at province and regency/municipality level) have 
supported the development and maintenance of roads, transportation modes and accommodation facilities continually in line with the TdS events held annually. Infrastructure development was intended to support the TdS events for sustainable tourism in West Sumatera. Central and local governments are aware that holding the TdS events surely involves stakeholder collaboration to meet the requirements of smooth roads, diverse transportation modes, and accommodation facilities. Thus, the infrastructures not only supported the TdS events held annually for ten-year period since 2009 but could also provide communities with great socioeconomic benefits for the long run.

\section{Transportation modes}

To support of the TdS events held annually since 2009, the number and quality of transportation modes increased, i.e. inter-city inter-provincial buses, trains, taxi, and travel. After four successful TdS events (2009-2013), the Government of West Sumatera Province improved the mode of railway transportation, increased the number of departures to support the TdS events, and to date has a railway connecting several regions, particularly Padang-Pariaman. The train transportation mode was developed again after Pariaman Municipality participated in the TdS event. Considering that the TdS events promoted http://ojs.unud.ac.id/index.php/eot the leading tourism attractions in Pariaman Municipality, such as Gondoriah Beach, the municipal government increased the number and quality of transportation modes because the beach was used as the start and finish locations for the $\mathrm{TdS}$ events. The Station in Pariaman Municipality was located in the tourism areas of Gondoriah Beach, so that tourists can directly enjoy the nuance of beach after getting off the train.

The Government of West Sumatera Province also cooperated with PT. KAI to provide a mass transportation, and trains were also ever used by $\mathrm{TdS}$ racer teams as transportation from Padang Panjang to Sawahlunto. The racers not only did mobility but enjoyed the beautiful natural scenery of West Sumatera. The increasing number and quality of railway supported the TDS events sustainably as sports tourism ones in the following years. The availability of transportation modes has increasingly supported the TDS events in West Sumatera. Number and quality of railway transportation modes increased over years, so did the trends of train passenger. The increase was directly proportional to the revenue from ticket sales. Passengers were from the Sibinuang Train, Padang-Pariaman, that has operated dailiy as well as the Dang Tuangku Tourism Train that has operated on Saturday, Sunday, and national holidays. 
In early 2016, the Government of West Sumatera Province established a partnership with PT. KAI to revive the railway that connects some regencies/municipalities. In addition, other transportation mode such as trans-Padang Bus was also available for the TdS events held annually in West Sumatera Province for ten-year period (2009-2018). It was operated by the Sub-Department of Transportation since 2014 to provide people with a proper transportation in Padang City.

The promotion as tourism city has been the Program of the Sub-Department of Tourism to support the development of tourism, being supported by the SubDepartment of Transportation and of Public Works in accordance with the focus determined by Heads of Local Governments. Several types of public transportation were available in West Sumatera i.e. inter-city inter-province bus, inter-city in province bus, rental/travel cars, taxis, tourism vehicles, and connecting transportation. Each transportation mode has its trends and supports the TDS held annually.

\section{Accommodation facilities}

Since the first TdS event in 2009, there has been a growth in accommodation facilities in various regions. The successful TdS events encouraged stakeholders in the http://ojs.unud.ac.id/index.php/eot regencies/municipalities traversed by the $\mathrm{TdS}$ racers to increase the number of adequate accommodations, especially star hotels in Padang City and Bukittinggi City. The increasing number of accommodation facilities can be seen from the increased number of hotel rooms in West Sumatera by 4,726 units in 2008 and increased by $58.66 \%$ to 8,056 units in 2015 (BPS, 2016). It is very reasonable because accommodation is an important part of the TdS events, considering that most racer teams (racers and officials), UCI members, and invited guests tend to act as tourists who come from outside the area and they really need adequate accommodation facilities as part of their tourism activity. Each regency/municipal government in West Sumatera improved the accommodation facilities for the development of sustainable tourism and the bargaining position as a reliable tourism destination also increased, especially if the areas were the grand opening locations of TdS events.

Each of the regions competed along with the TdS events to open new investment opportunities for new accommodation facilities. The cities such as Padang and Bukittinggi have accommodation facilities with adequate quantity and quality to support the TDS events held annually. Such accommodation facilities are needed 
because the TdS events moved from one location to another, every mobility goes hundreds to thousands of kilometers, and not all participants could return to the starting point. Both the committee and participants who did not return to the starting point stayed at the finish location. This led to the development of five-star hotel accommodation facilities, especially in cities such as Padang and Bukittinggi. Padang City was the grand finish location in the TdS events because it was able to provide five-star hotels with adequate quality for international tourists. To support the TdS events, Tanah Datar Regency, for example, also built a 4-star accommodation facility. In addition, 4-star hotel was built in Batusangkar to support the TdS events and tourism in general. The TdS events were also supported by the increased investment in hotel development, at least 4-star in other regencies/municipalities, such as in the Anai Valley, Padang Pariaman Regency, as a form of cooperation between regency government and the private sector.

\section{CONCLUSIONS AND SUGGESTIONS}

The TdS events have been successfully held for ten-year period (2009-2018) in West Sumatera. Destination Management for TdS was influenced by stakeholder collaboration http://ojs.unud.ac.id/index.php/eot between central, provincial, and regency/municipal governments in West Sumatera. The stakeholder collaboration in the TdS events could be seen from event coordination, contribution, and tourism development and promotion. Such coordination as a part of destination management and marketing has led to a harmonious cooperation in the development and improvement of infrastructures, i.e. roads, transportation modes, and accomodation facilities with increasing quantity and quality in an integrated manner for the development of sustainable tourism along the TdS events held annually for ten-year period (20092018).

In the availability of increasingly adequate infrastructures, racer team and its officials as international sport tourists in the TdS events could enjoy the traveling on the increasingly even and smooth roads with high level of comfort and safety to destination. They could also easily access diverse transportation modes, such as trains, trans-West Sumatera buses, rental/travel cars, tourism buses, connecting vehicles and quality cargo taxis. Provincial, regency, municipal and city governments should build a proper destination manegement and collaboration through coordination among the relevant stakeholders in the provision of shared budgets, event coordination, development 
and promotion of tourism and destination management with impacts on the development and improvement of even and smooth roads, diverse transportation modes, and accommodation facilities. Policies should be implemented in order that racer teams and their officials, invited guests, and the organizing committees can stay overnight at each start or finish location in each regency and municipality involved and encourage people in each region to watch the event for the development of tourism included in destination management.

\section{REFERENCES}

Ardani, E.G., (2017). The Importance of the Venue Selection in an Event Organization Case Study: Special Event Organization Rencontre Alumni Entreprise $1 \&$ 2, E-Journal of Tourism Vol.4. No.1. (2017): 4654.

Baade, R.A. dan Matheson, V.A. (2003). Bidding for the Olympics: Fool's Gold? Transatlantic Sport. London: Edward Elgar Publishing.

Brown, G., Chalip, L., Jago, L., \& Mules, T. (2004). The Sydney Olympics and Brand Australia. Dalam Morgan N., Pritchard A., \& Pride R. (Eds.), Destinations branding: Creating the unique destination proposition. Oxford, UK: Elsevier ButterworthHeinemann.
Byrd, E. T. (2007). Stakeholders in sustainable tourism development and their roles: Applying stakeholder theory to sustainable tourism development. Tourism Review, 62(2), 6-13. doi: $10.1108 / 16605370780000309$

Deenihan, G., Caulfield, B. (2015), "Do tourists value different levels of cycling infrastructure?", Tourism Management, Vol. 46, pp. 91-101. Doi:

https://doi.org/10.1016/j.tourman.2014 .06 .012

Getz, D. (2007). Event Studies: Theory, Research and Policy for Planned Events. Oxford: ButterworthHeinemann.

Getz, D. (2008). Event tourism: Definition, evolution, and research, Tourism Management 29 (2008) 403-428

Gunawijaya, J., and Pratiwi, A., (2016). Destination Development for Rural Tourism Area in Wanayasa, Puwakarta, West Java, Indonesia, EJournal of Tourism Vol.3. No.2. (2016): 88-95

Hadzik, A., and Grabara, M. (2014). "Investments in recreational and sports infrastructure as a basis for the development of sports tourism on the example of spa municipalities", Pol. J. Sport Tourism, Vol. 21, pp. 97-101. Doi: 10.2478/pjst-20140010 .

Kencana, E.N., (2019). The Role of Local Government in Fostering the Economic of Community: A Lesson from Tourism Development at Nusa Penida Islands of Bali, E-Journal of Tourism Vol.6. No.1. (2019): 119129

Lohmann, G., and Netto, A.P. (2017). Tourism theory concepts, models and systems, CABI, Oxfordshire. 
Ritchie, J. R. B., \& Smith, B. (1991). The impact of a mega-event on host region awareness: A longitudinal study. Journal of Travel Research, 30(1), 3-10.

Sharpley, R. (2009). Tourism development and the environment: Beyond sustainability? Earthscan. Oxon, UK

Simanihuruk, M., (2019). Tourist Attraction and Tourist Facilities Intentions to Visitor Satisfaction: Case of Sindang Barang Cultural Village, E-Journal of Tourism Vol.6. No.2. (2019): 210-224.

Sitepu, E.S., (2019). Improving Tourism Destination Management Through Sustainable Tourism Development Model A Case Study on TSR., EJournal of Tourism Vol.6. No.2. (2019): 252-268.

Smith, A. (2005). Reimaging the City: The Value of Sport Initiatives. Annals of Tourism Resarch, 32: 217-236.

Susanti, R., Priyambodo, T.K, and Janianton Damanik, Soeprihanto, J., (2017). Journal of Humanities and Social Science, Vol. 22 (10).

Swarbrooke dan Horner, Swarbrooke, J., Horner, S. (2001). Business travel and tourism, ButterworthHeinemann, Jordan Hill, Oxford. Doi: 10.1016/B978-0-7506-43924.50012-4

Timareva, S., Arabska, E., and Shopova, I., (2015). Role of Destination Management and Marketing Organizations in Regional Development, Trakia Journal of Sciences, Vol. 13, pp. 96-102. 